\title{
Staging the Resurrection: A Public Theological Practice
}

When in the 2013 edition of The Passion, in contrast to previous editions, the resurrected Jesus appeared not on top of a tower, but beside a pool of water on a level with the audience, his apparition drew my attention to the possible theological implications of the staged ritual. ${ }^{1}$ It made me wonder whether, or how, the producers of the event were practising theology. Practical theology has been identified as, among other things, something which takes place amid the reality of daily life. As Bonnie Miller-McLemore has observed, "it develops in the midst of ordinary life circumstances", amongst the constitutive practices that shape faith among believers in home and society. ${ }^{2}$ But practices of theology can take place irrespective of whether or not faith is actively or purposefully embodied in these practices. As this chapter will show, producing an event that stages a crucial element of Christian tradition in the public sphere is not necessarily a public practice of faith, but it is a form of embodied practical theology. In what follows, I will excavate the public practical theology of the resurrection as constructed by the organisers of The Passion.

Public theology is generally understood to be a reflective, or even reflexive, practice which is undertaken by (academic) theologians, although there are exceptions. ${ }^{3}$ South African theologian Andries van Aarde, for example, in

1 This chapter is a thoroughly revised and updated version of an article that was published earlier as Mirella Klomp, "Staging the Resurrection: The Public Theology of Dutch Production and Broadcasting Companies". International Journal of Public Theology 9/4 (2015), 446-464.

2 Miller-McLemore, The Wiley-Blackwell Companion, 7.

3 Cf. for example the 33 places where 'practical theology' is mentioned in a practical theological handbook such as Miller-McLemore, The Wiley-Blackwell Companion. Here, the term is mostly used to refer to a practice whereby practical theologians link public theology to the communities around them, e.g. by contributing to public debates. Practical theologian Elaine Graham's Between a Rock and a Hard Place is worth mentioning here. In her book she proposes a Christian apologetics of presence in public life. Although I also understand my task as practical theologian as 'doing theology in the public sphere' (cf. Chapter 8), at the same time, I take public theology to be something that can be practised by different actors (cf. 'A multi-actor practice', below). Practical theology is performed not only theologians, but also by others who practice theology (sometimes unintentionally) in the public sphere. 


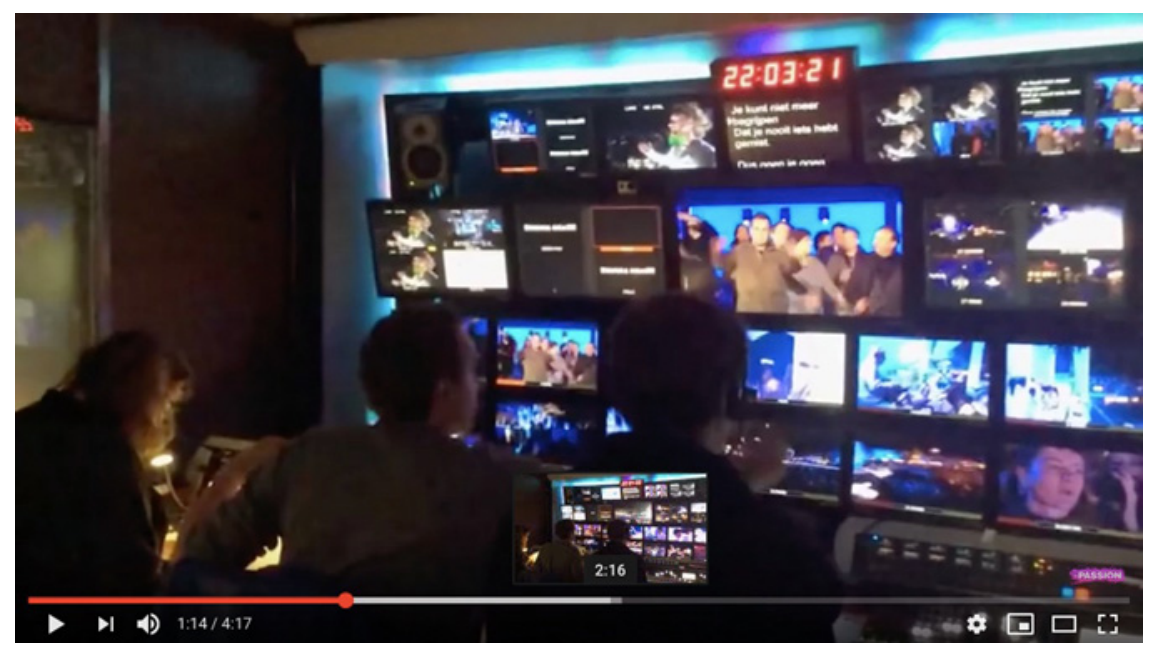

FIGURE 14 Television director David Grifhorst in the mobile production unit in 2015 A screenshot from the Youtube-video in which he is energetically directing the final scene that staged the resurrection (see the resurrected Jesus left and right of the clock in the upper row of screens). "Finale van The Passion 2015 vanuit de regiewagen", The Passion, streamed on April 4, 2015, YouTube-video, 4:17, https://www.youtube.com/watch?v=kkGfcFB8r-8. Last accessed May 10, 2020.

2008 wrote that in his opinion "'public theology' is not about theologians or pastors 'doing theology' in the public square. Public theology is the activity of the film directors, artists, novelists, poets, and philosophers". ${ }^{4}$ Building upon this viewpoint, I claim that public events such as The Passion constitute practices in which public theology and practical theology intersect at a 'grassroots level'.

In the following sections, I will show how the making of an event like The Passion is a way of performing public practical theology. Moreover, I will demonstrate how TV producers did more than simply present one of the most fundamental elements of Christian tradition. Rather, without being very aware of the ins and outs of their theologising, they publicly staged a theology of the resurrection of Jesus Christ. This is both a relevant and an exciting source of practical theological knowledge.

4 Andries van Aarde, "What is 'theology' in 'public theology' and what is 'public' about 'public theology'?" HTs Teologiese Studies / Theological Studies 64, no. 3 (2008), 1213-1234. Dor: 10 $.4102 /$ hts.v64i3.81. 


\section{Staging the Resurrected Jesus}

The resurrection, which, as many musical passion performances and compositions have demonstrated, is not, strictly speaking, part of the actual passion narrative, has been staged at the conclusion to all performances of The Passion. Towards the end of the story, after a somewhat detailed description from Pontius Pilate of what happens physically to a body as it is crucified in the first five editions, and after a song sung by Mary, the mother of Jesus in all editions, The Passion has always ended with a description from the narrators, followed by an apparition of Jesus depicting his resurrection. This resurrection was, however, introduced, suggested and staged differently in each of the editions. On the basis of a full examination of the final scenes, I will first describe the development of the different introductions to these scenes by the narrator over time, I will then discuss the staging of Jesus' apparition and the lyrics which he sang in three particular editions of The Passion in 2011, 2014 and 2019. ${ }^{5}$

\section{Introductions to the Finale}

The words by means of which the narrator brings the event to an apparent close after the death of Jesus are actually the introduction to the resurrection, since, after this 'ending', the final scene portrays the resurrected Jesus. These words and their tone have slightly evolved over the years. Anticipating the risk of a negative reception for The Passion in the first edition, since no one knew how the event would be received in secularised Dutch culture, the organizers chose to let the narrator mockingly suggest the resurrection of Jesus, rounding off the performance as follows:

It is finished, so to say. Some people said that he will rise from the dead. I also learned that Jesus himself said this a couple of times. [The narrator mockingly chuckles:] Don't you believe it? ... Well, we all know that this story does not have a happy ending. And this ending may not be a very good ending, but hey... we are, after all, in fucking Gouda! ... Thank

5 The resurrected Jesus appeared on top of a building adjacent to the city square where the organisers put up the stage in 2011 (the tower of St. Jan's Church, Gouda), 2012 (the Erasmus Bridge, Rotterdam), 2015 (the Alpha tower, Enschede), 2018 (AFC Ajax' Johan Cruyff ArenA, a temple for soccer fans, Amsterdam Bijlmer), 2019 (the Dordrecht Minster). In four editions, Jesus appeared close to the audience: at the Court Pond in The Hague in 2013, on the square in amidst the people in Groningen in 2014, in Amersfoort in 2016, and, together with Peter, in Leeuwarden in 2017. 
you for coming. From the Market Square in the city centre of Gouda on Maundy Thursday 2011: thank you, good night! 6

The following year, the positive reception of the first edition seems to have opened the way for a change in tone on the part of the narrator, becoming more neutral and less sceptical. At the end of the second edition, the narrator rounds off the event with a question:

It is finished, so to say. Maybe this is not really a nice ending. ... And what was the use? ... Some people said that he will rise from the dead. According to the Bible, Jesus himself said this a couple of times. Whether you believe he did, is up to you... And with this, our story seems to have come to an end. Or has it...?

In 2013, the text of the narration was similar, remaining neutral and open to a variety of possible interpretations, however, the second sentence had been altered into a tongue-in-cheek statement: "Maybe this is not really a Hollywood happy ending..."

As in the 2016 edition, the closing narration of the 2013 edition was turned into something both lengthier and bolder. ${ }^{7}$ The allusion to the apparition of Jesus slowly began to resemble a 'sermonette', or very small sermon. Sermonettes contain a number of elements: they name a particular situation (in this case the passion event in the city square), they tell a joke (or wordplay), and they offer a Biblical/scriptural equivalent for the situation, ${ }^{8}$ followed by a wrap-up or explanation which ties the illustration and scripture together in a meaningful way for the audience. ${ }^{9}$ Jokes have been a part of the narrator's script since the first edition. In 2011 this was a cynical joke on the city of Gouda, in 2013 a tongue in cheek statement referring to Hollywood (for the 2014 joke, see below). But, aside from jokes, since the 2016 edition the narrators have come to make clearer theological statements. The Biblical/scriptural/dogmatic component of the sermonettes in particular has taken a more emphatic stance: "Death and suffering do not have the final say. I repeat: death and suf-

6 English translations of Dutch spoken words and song lyrics in this chapter are mine.

7 I have no information on why the length and boldness of this particular part increased. Perhaps it was due to the general positive reception of The Passion, and perhaps the makers of this public event also felt urged to make a statement since the 2016 edition took place two days after the terrorist attacks in Brussels (see Chapter 6).

8 E.g. biblical verses, but I would broaden this further to include dense dogmatic articulations.

9 Cf. Dennis Burgess, The 6o Second War. A Collection of ADHD Sermonettes (Scotts Valley, CA: Amazon, 2015), introduction. 
fering do not have the final say" (in 2016), "Together, we decide what wins: love or hate. If only everybody would love the other like himself, this story would by no means be an end, but rather a new beginning. Because to fall [the narrator wags his finger and pauses] only becomes a problem when at the end of this story no one gets [back] on their feet" (in 2017). And in the 2019 edition:

This story began as a story of hope. How love would conquer fear. That no one would have to be alone any longer. And now? Now, a man who was misunderstood has been crucified and died. If Jesus, out of love, wanted to understand the deepest loneliness and misery of human beings, then he really went a long way down that road. With far-reaching consequences: dead, end of story. Or not?

The Bible describes how Jesus arose from the dead after three days, and that, by doing so, he confirmed his message that love indeed conquers all, even the pain of death. You either believe that this really happened, or you do not. Anyhow, Jesus was there, and when you really look carefully, you see that he is still here. Maybe in you, and perhaps today with me. The message of Jesus after so many centuries is clearly a message of power and of inspiration to care about each other, to reach out to the other, to make time for fellow human beings who all ill, who are strangers, who are held hostage, who differ from you. So that nobody is alone.

Thus, over the course of nine years, and probably due to the generally positive reception of The Passion, the concluding words that introduced the final scene evolved from a rather sceptical statement regarding the impossibility of somebody rising from the dead, to a hermeneutically more developed theological statement that linked Jesus to particular (groups or categories of) people in society. A message, moreover, with clear didactic aspects, teaching that Christ is still present today. I will continue discussing how the apparition of Jesus was staged in the editions of The Passion in 2011, 2014 and 2019.

\section{Gouda 2011}

In 2011, after the concluding words, the lights in the square were switched off. It was suggested that the show was over. The orchestra nevertheless continued to play dissonant sounds, and search lights started to cross the square. Then, suddenly, spotlights illuminated the tower of the monumental St Jan's Church right behind the stage, where the Jesus character appeared, singing. ${ }^{10}$

10 The Jesus character in all editions appeared without any wounds on his hands (or feet): after his death he did not visibly differ from before. 


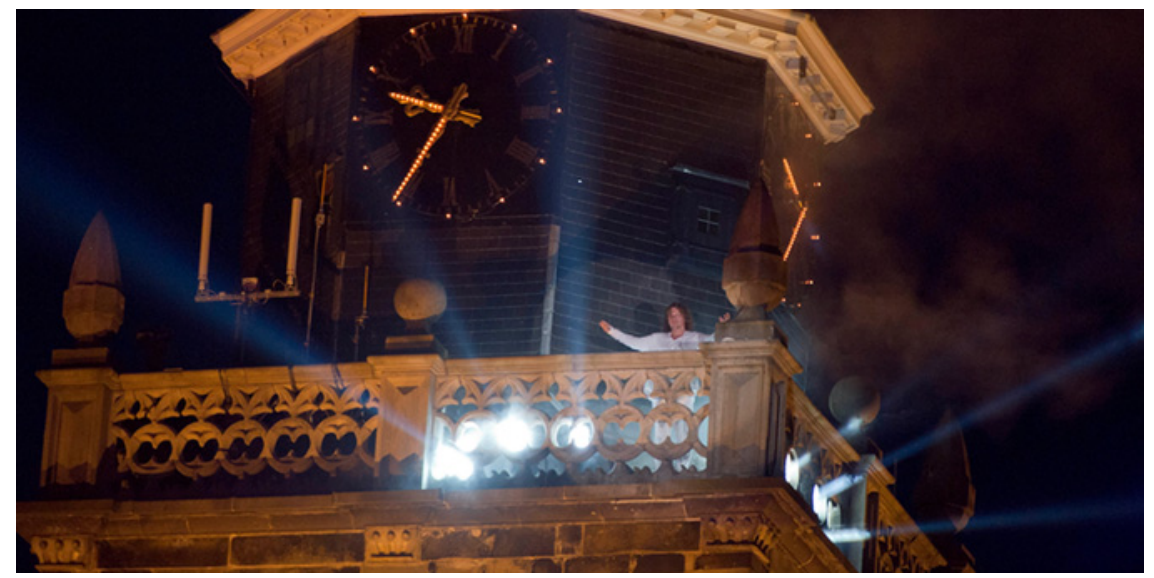

FIGURE 15 Singer Syb van der Ploeg as the resurrected Jesus on the tower of the St Jan's Church in Gouda Pното: (c) ANP

The first verse of the song, he sang a cappella, so that no attention was drawn to anyone other than him; later on, the orchestra accompanied his singing. People down on the square waved with the glow-in-the-dark devices which they have received when they entered the square; others sang along. The resurrected Jesus was staged up high, dressed in white clothes, standing with his arms wide open, ${ }^{11}$ and he sang the chorus of a very well-known Dutch pop song, the lyrics of which read:

Now give me your fear, I give you hope in return.

Now give me the night, I give you a new day in return.

As long as I do not lose you, I am sure I can find my way with you. ${ }^{12}$

The original lyrics have a number of different metaphorical layers. In the context of The Passion, the lyrics maintained these different layers, but some of their meaning was altered. For instance, in the verses, the main figure lures a second person into staying overnight ("This will never happen again if you decide to stay with me tonight: when you wake up, you will find yourself laughing

11 Interestingly, no painted wounds were visible on his hands: the narrator told the audience that Jesus was crucified, but in this presentation, after his death, he appeared unhurt.

12 The translation is mine. Full lyrics of "Geef mij je angst". André Hazes. http://www .songteksten.nl/songteksten/333o/andre-hazes/geef-mij-je-angst.htm. Last accessed May 10, 2020. It was a cover version of a song by André Hazes, one of the most famous Dutch folk singers in recent history. A previous cover version was sung by Guus Meeuwis at Hazes' own funeral that took place in a football stadium in 2004. 
again".) In the new context, in the mouth of Jesus, this song has the potential to become more of an offer of help for the spectators, or an invitation to follow him. The implied sexual meaning of the lyrics may, then, have moved to the background. Nevertheless, whether or not they have put their faith in God or allowed Jesus to walk beside them in life, whether or not they have believed in the resurrection of Christ, each person decided for themselves how to ascribe meaning to the song. Indeed, this ambiguity was at the heart of the presentation of the resurrection in this first edition of The Passion. The song can thus be understood as a call for trust: it was an invitation to confide all fear and all darkness and night to the first-person narrator who, in this case, took the form of the risen Lord who was staged on high. Those who did confide all this darkness were promised that they could receive hope and a new day in return. Given the organizers' aim of familiarising a wide audience with the narrative of Jesus, the physically and textually shaped theological message may have been that the risen Lord offers every individual a new start, a new day; he offers every person who decides to put his/her trust in the Lord the hope of resurrection. ${ }^{13}$

\section{Groningen 2014}

On the night before the performance of the fourth edition of The Passion, the producer and broadcasting companies made a last-minute change to the staging of the resurrection. They had planned to let Jesus appear on the tower of the Martini Church - one of the highlights of the city of Groningen, close to the Vismarkt, the big square where The Passion would be performed. But, a few days before the event, they decided that this church tower would be too predictable a location for the appearance. "After all", one of the press officers told me, "it is also a show, and it is important that it has some surprise to it as well. So, therefore we decided to stage the resurrection in amongst the people in the square. And then we thought, 'Oh! To have him appear amongst the people is actually quite meaningful!"'14 Clearly, after their directorial/production decision, a theological observation regarding the newly created reality followed. The element of surprise during the performance was heightened by the fact that the producers allowed the narrator to play with the audience and their expectations, and with the famous slogan that is used for in marketing for the city and province of Groningen. This Dutch slogan is a play on words

13 My reconstructions of the staged public theology in sections 3.1-3.4 are based not just on the quoted lyrics, but on the lyrics of the entire song.

Telephone interview by M K with Reinder van Dijk, May 8, 2014. 
that combines the geographical location of Groningen in the far north of the country with the claim that Groningen delivers quality in its events, products and services. In previous editions, the narrator had looked up to suggest that Jesus would appear somewhere in that direction. This year too, he said:

It is finished, to put it nicely. Whether or not you believe that this is the end of the story is up to you. The fact that we still tell this story here, 2000 years later, on the Vismarkt, leads me to the question of whether the death of Jesus may not be the end of the story... Some people said that he will rise from the dead. According to the Bible, Jesus himself said this a couple of times...

The slogan of this beautiful province is: 'Nothing tops Groningen...' Or...?

The narrator looked up in a searching manner as sound and lighting effects were deployed, and the cameras focused in on the tower of the Martini Church. Then the audience heard the singer who played the role of Jesus sing:

Look up, to the sun; do not search for answers;

let it go and hold on to me.

This road leads itself, it leads you to the future;

this cloud will quickly pass by. ${ }^{15}$

But Jesus did not appear on the tower. All of a sudden, the cameras moved rapidly downwards and showed the figure of Jesus standing among the audience in the city square. The artistic director decided to place his appearance among the audience, right there, in their midst. In this way, Jesus appeared in a place where no single TV viewer had expected him to appear, although the people at the back of the square naturally must have noticed that something was going on. The Jesus character touched, or suggested that he touched the people surrounding him. The audience in his immediate neighbourhood took pictures with their smartphones.

The call of the song to 'look up' contradicts the physical presence of the Jesus figure amidst the people. The lyrics can be interpreted as conveying a theological image of Jesus as a guide to follow, or maybe of Jesus as the Way, as the road that will lead to the future. This road, Jesus, then becomes the future,

15 The translation is mine. This final resurrection song, as in 2013, was a cover of a song by the duo Nick and Simon. The verses were left out; only the chorus was sung and repeated. The full lyrics of "Kijk omhoog". Nick en Simon. http://www.songteksten.nl/songteksten/ 76349/nick---simon/kijk-omhoog.htm. Last accessed May 10, 2020. 


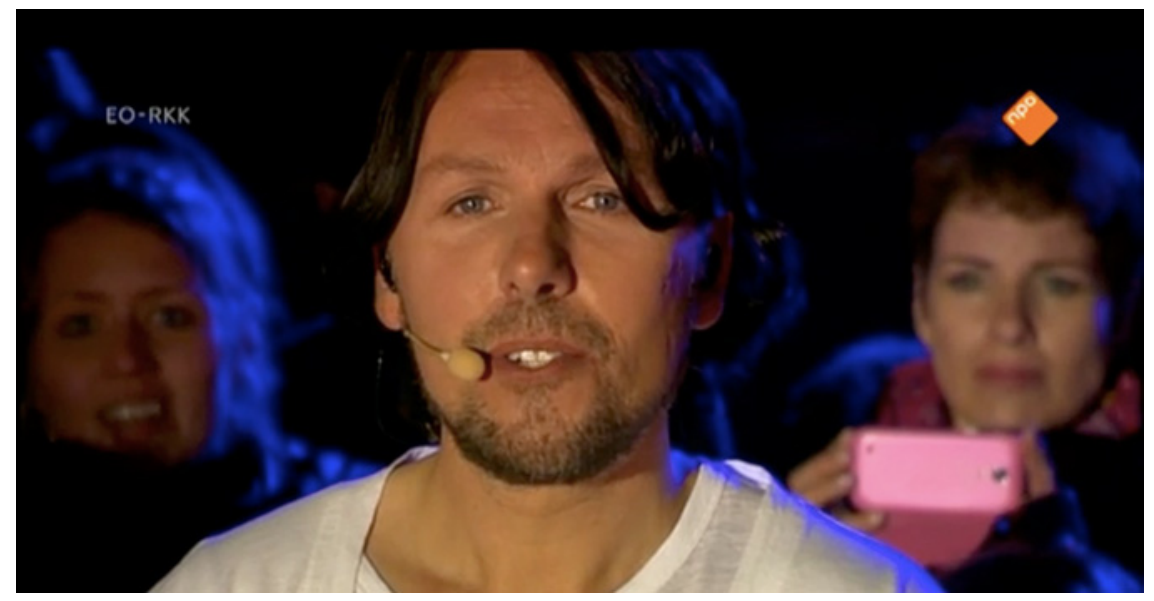

FIGURE 16 The resurrected Jesus (by singer Jan Dulles) appearing amongst people in the square in the 2014 edition of The Passion

SCREENSHOT FROM THE ONLINE BROADCAST OF THE PASSION

in the sense that death is not the end, and there is no dead-end with him. Although this theological construction of The Passion is totally at odds with, for instance, the narrative of Mary Magdalene who takes Jesus for the gardener, in which Jesus says: "Do not hold on to me, because I have not yet ascended to the Father" (John 20:17), the suggestion here is different: holding on to the risen Lord helps a person to let go of everything else (the verse preceding the chorus describes a head full of worries), and to stop searching for answers that apparently do not solve everything. In this reading, in the end, the cloud (of confusion, incomprehension, misunderstanding?) will pass by and the unexpected will occur: Jesus will bring light/enlightenment. Another reading is that, in line with Luke 24:36-53 where holding (on to) Jesus is encouraged so as to emphasize that his appearance is real, Jesus still appears amidst the people: he is still among people right up until the present day.

The choice of the organisers of The Passion to let the resurrected Jesus appear amidst the crowd while singing these lyrics is a statement that makes a clear and fairly direct suggestion regarding the meaning of Jesus: he is a guide to the future, or even the Way. It also makes a strong suggestion as to what an attitude of faith might look like: letting go of everything else and holding on to Jesus; it is staged theology and, more-specifically, staged Christology.

\section{Dordrecht 2019}

Having concluded the event by saying that the message of Jesus is a strong and inspiring call for people to care for others, "so that nobody is alone", the narra- 


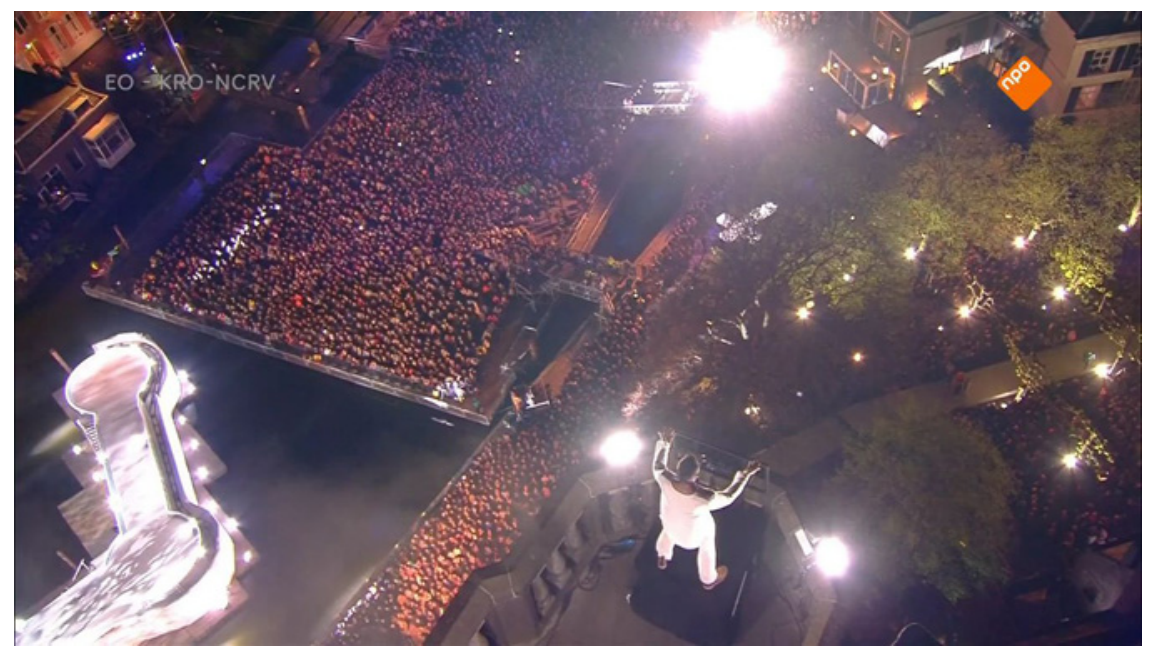

FIGURE 17 The resurrected Jesus (by Edwin Jonker) appearing on top of the Dordrecht Minster above the square in the 2019 edition of The Passion SCREENSHOT FROM THE ONLINE BROADCAST OF THE PASSION

tor gazed up to the tower of the Dordrecht Minster, where the resurrected Jesus immediately took over, singing assuringly to the audience: "You are not alone". This edition played less with the surprise of the apparition compared to previous editions: after mentioning the potential of the performance's message to help people feel less alone, the ritual immediately continued with a proclamation of this reality by the resurrected Jesus, using the chorus of another Dutch pop song:

You are not alone,

I will be there for you.

When it's all far too much sometimes,

I will always be there.

No, you are not alone,

if you need my ear to bend,

if life feels too much,

I will always be there. ${ }^{16}$

16 The translation is mine. Full lyrics of "Je bent niet alleen" available on https:// songteksten.net/lyric/2430/91927/thomas-berge/je-bent-niet-alleen.html. Last accessed May 10, 2020. 
Shortly after the chorus and the verse sung by Jesus, the screens showed footage of the main characters and of the disciples helping out other people: the man who played the role of Peter spoon-feeding a handicapped woman; a female disciple standing together with another young women looking at a smartphone and smiling before the disciple helps to push the wheelchair of the other woman; a guy sitting sadly and alone in a bar before being joined by another male disciple. The theology of this resurrection is that Jesus is present and appears in every person as they keep another person company, spend time with people who are having a hard time, or offer help to those in need practical support. It is a theology of presence - whether around the kitchen table, outside in the streets or in a pub, after and because of the resurrection of Jesus, resurrections among ordinary people can occur in every place where fellow-creatures are looking after their neighbours.

All nine staged appearances expressed theology in their own ways through their staging, and in their choices surrounding screening and the use of lyrics. Every scene of The Passion could be analysed in a similar way, from the recitation of the story by the narrator, to the staging and lyrics used in the scenes of Jesus entering the city, the last supper, the betrayal by his friends, the mocking of the man to be crucified, and of his death. The analysis above shows that a decision to stage the most crucial narrative in Christian tradition in a late-modern 'secularised' society does not necessarily lead to a watered-down version of the resurrection: The Passion is not merely a sound and light show, it is staged theology, and this theology cannot simply be dismissed as 'sloppy'. There has never been (nor will ever be) an authoritative and unchanging model for performance either of the passion or of any other Biblical event: right up into the present day, these forms have always been part of a tradition which constructs, deconstructs and reinvents the presentations of a story that circles around the suffering, death and resurrection of a man who is called the Son of God. In all their different forms, stagings of this narrative express a variety of different theological meanings, and The Passion is no exception.

\section{Production and Broadcasting Companies Doing Theology}

I have isolated the scene staging the appearance of the Jesus character from the rest of the event in order to focus on the ways in which the organisers of The Passion actively expressed theological meaning, and thus asserted theology in public. In order to further interpret the latter, I lean on the theory of John McClure, who, in his book Mashup Religion, challenges the general academic 
conception of the nature of theology by pointing to the world of pop music. ${ }^{17}$ Using contemporary music-making - in which a song is written in relation to a tradition (either in continuity or discontinuity), is sampled across traditions and genres, remixed and mashed up using the latest technologies - as a metaphor, McClure explains how theological invention arises when a mashup of the traditional and the novel is created. McClure argues that "theological invention is a matter of stylistically layering four central authorities (tracks): Scripture, culture, theology and reason". ${ }^{18}$ Referring to the aesthetics of HansGeorg Gadamer, he points out that song-writing within a tradition is a deeply hermeneutical practice: it "is created and comprehended primarily within the horizon of meaning represented by a historical tradition. (...) All new, autonomous, and authentic words are improvisations on a living tradition and gain heteronomy by being beholden to traditions of communication long established and revered within the community itself". ${ }^{19}$ Song-writing out of a tradition means "working from models within a tradition, while "deliberately breaking conventions and forms", adding a "twist and stretching boundaries". 20 McClure pursues the use of popular music-making as a metaphor throughout his book in order to propose a potential shift of emphasis in the theological education of students: they could learn how to 'do theology' by acquiring the skills and knowledge to 'cover' and 'riff on' particular exemplary works within existing theological traditions. ${ }^{21}$ Students can thus learn to handle theological themes and concepts, and to carry these forward in new ways. Focusing "attention on small patterns of behaviour, types of words or phrases, colours, sounds, attitudes, styles, furnishings, habits, expressions", they begin to relate reality to the larger scheme in which these realities exist. More than just applied theology, they thus develop a lived theology. ${ }^{22}$

I suggest that this is exactly what the production and broadcasting companies are doing in case of The Passion. They deal with theological concepts and themes which they then carry forward in a new way. Revitalising a musical form that is deeply rooted in historical Christian traditions, they engage in a

\footnotetext{
17 John McClure, Mashup religion. Pop music and theological invention (Waco, TX: Baylor University Press, 2011).

18 McClure, Mashup religion, 9. McClure makes clear that "not all theological compositions will use all of these tracks, and they will not always be used consistently", McClure, Mashup religion, 55 .

19 McClure, Mashup religion, 15.

20 McClure, Mashup religion, 17.

21 McClure, Mashup religion, 18.

22 McClure, Mashup religion, 37-38.
} 
Christian hermeneutical practice. As they sample Dutch hits, and remix the passion narrative using all kinds of digital technologies, whilst simultaneously engaging through social media, they create a mashup passion that conveys Christian theological messages in a contemporary form. Whether production and broadcasting companies are aware of it or not, through their involvement in the performance of The Passion, they stylistically layer together the four aforementioned central authorities. The 'Scripture track' takes the passion narrative as depicted in the four canonical gospels as its principal point of departure. This track is explicitly referenced when, just before the Jesus character appears, the narrator states that: "Some people said that he will rise from the dead. According to the bible, Jesus himself said this a couple of times..." The 'culture track' becomes visible through, among other things, the organisation of a large multi-media event, the live broadcast of that event, the performance of Dutch pop songs, and the use of technology. In the 2014 construction of the resurrection, the cameras that quickly panned down from the Martini tower in order to display the Jesus figure standing among the audience on the city square are one of the key elements that serve to constitute the culture track. The shape of the 'theology track' has already become visible to us through my earlier description of the theological interpretations that I uncovered above. The 'reason track' (McClure also calls this the 'message track' since it relates to the understanding of religious truth) is harder to discover, particularly because The Passion combines the transmission of theological meaning with its explicit and oft-repeated message that it is up to the meaning maker to decide on the nature of religious truth for themselves.

By layering these four tracks together in a passion event performed in the public sphere, the organizers constructed a theology of the resurrection. This theology is, itself, a performed theology as a natural consequence of the public staging of the event. An academic reconstruction of constructed theologies, as delivered in this chapter, is clearly necessary in order to be able to demonstrate both the nature of this performance as a public theological event and the means by which this performance is carried out. This does not, however, alter the fact that the production and broadcasting companies are also engaged in the performance of public theology.

\section{Public Theology as a Multi-Actor Practice}

In Chapter 2, we claimed that, in late-modern times, the immaterial religious heritage of Christianity (the bible, ritual repertoires, symbols, musical forms, etc.) constantly participates in processes of movement from the ecclesial to 
the cultural or public domain (and vice versa). ${ }^{23}$ Through these processes, religious immaterial heritage moves outside of ecclesiastical structures so as to become a common asset. As such, it simultaneously leaves behind existing ecclesial frames of interpretation, such as those of religious doctrine. Given the fact that western churches are rapidly losing members, these churches are no longer the central institutions in charge of the interpretation of this heritage. People increasingly decide for themselves what the things around them mean: they attribute meaning (including religious meaning) according to their own particular collection of interpretive frames. The way in which religious immaterial heritage (including rituality or, as in our case, large-scale musical forms) is experienced and obtains meaning is affected by the tendency towards individuality that is part of modernity as people are able to deal with these things in their own individual ways. Everyone creates his or her own system of meaning: we are all 'like a spider in a unique web' ${ }^{24}$ As liturgical studies scholar Marcel Barnard put it in the year 200o: "Rites and symbols are increasingly becoming an expression of the unique person which we each are. They have, so to say, become expressions of our own identity. Thus, in addition to reproducing meanings, we are also appropriating them. Moreover, we are not only appropriating them collectively, as groups, but also more and more individually". ${ }^{25}$

In Chapter 4, we discussed how late-modern society is characterised by a 'plural authority structure'; as processes of meaning-making and evaluation have changed, power and authority are now divided. This means that, in processes of interpretation and meaning-making, the dominant ecclesiastical interpretations and meanings which come from the church no longer naturally prevail. This loss of authority on behalf of the church is in keeping with a decline of authoritative institutions in general. Authority and power in the present day no longer fall to central institutions. Just like the church, academia, which has been (some would say: used to be) another authoritative institution in the Western world, seems now to have lost some of the authority which it previously possessed over the course of recent centuries.

23 Gabriël van den Brink, "De migratie van het goddelijke. Over geloof en kerk in de moderne maatschappij”, in Geloven in het publieke domein: Verkenningen van een dubbele transformatie, WRR Verkenningen 13, eds. W. van de Donk et al. (Amsterdam: Amsterdam University Press, 2006), 417-433; Marcel Barnard, “Bijbellezen als textiele werkvorm”, 431-432. Marcel Barnard, Liturgiek als wetenschap van christelijke riten en symbolen (Amsterdam: Amsterdam University Press, 2000), 11 (Inaugural address University of Amsterdam). The translation is mine.

25 Klomp, The Sound of Worship, 4. 
The common man seems often to consider academic reflection and scholarly interpretation to be 'just another meaning'.

Just as the interpretive frame of the church has become just one of many possible interpretive frames, so is the practice of public theology no longer solely reserved to scholars. Academia is not the only place where public theology can be located: in shaping and staging The Passion and thus constructing temporal and situational theologies of the resurrection, the production and broadcasting companies also asserted public theology. Obviously, their public theology is not academic in character and thus not similar to academic public theology (nor does their output take the shape of a scholarly article or book). Their public staging of an event, in the form of The Passion, nevertheless constitutes a ritual practice which has involved a degree of theological reflection. By transforming The Passion into a large media event and simultaneously helping to shape its content, the organisers theologise: they theologically think through their choices, and the event itself reflects their theology. Indeed, The Passion itself is the public embodiment of the organizers' theologising. In their representation of the resurrection as part of a public event, they served to construct theology before the eyes of millions of people.

"Public theology is an engagement of living religious traditions with their public environment", wrote Sebastian Kim in the very first issue of a journal of Public Theology in $2007 .{ }^{26}$ This is exactly what the production and broadcasting companies did: by organising The Passion they engaged with the cultural sphere of everyday life. If academic public theology is to make sense in latemodern society, it has to take societal developments very seriously, and thus also to acknowledge both that the circle of public theologians has considerably widened and that the forms of public theology have begun to diversify. Understanding practical theology as public theology, as I myself do, this acknowledgment offers both important opportunities and challenges when it comes to working and interacting with theological partners in society. These, in turn, will serve to advance the practice of public theology as a whole and contribute to the prominent place of theology in the public sphere.

\section{Ritual Criticism}

Having said this, a particular task remains for the academic practical theologian who practices public theology: she has particular knowledge that makes her an expert in her field, just as broadcasting companies are experts in the

26 Sebastian Kim, "Editorial”, International Journal of Public Theology 1, no. 1 (2007), 1-4, here 2 . 
field of making television and just as particular municipal services have experts who support the organisation of large events in their cities. In this chapter, I have described the ritual creativity that led to a staged theology of the resurrection in various editions of The Passion, and have interpreted the theology of this ritual by means of McClure's theory. Before concluding this chapter, I want to offer an assessment of the ritual in an attempt to "understand specifically in the service of practice". ${ }^{27}$ In the field of ritual and liturgical studies, this assessment is termed 'ritual criticism'. This is a necessary companion to ritual creativity, according to one of the founders of Ritual Studies, Ronald Grimes, ${ }^{28}$ and it is inherent part of ritual play, as Ute Hüsken has claimed. ${ }^{29}$ I will introduce a ritual criticism perspective in order to evaluate the staging of the resurrection, more particularly, the introductions of the final scene by the narrators, with the aim of offering a constructive, or even reflexive, assessment of the rite. ${ }^{30}$

From an etic point of view, I consider the change in the style of the words which introduce the appearance of Jesus and which I elaborated on at the beginning of this chapter, to be a 'performative infelicity': throughout the play, the narrators have acted as presenters of the ritual event, but shortly before the final scene they suddenly withdraw from the play. They zoom out, if you will, in the act of offering an interpretation of the event. ${ }^{31}$ After these interpretative words, the audience is expected to zoom in again, and the play continues when the final scene stages the appearance of Jesus. Towards the end of the event, the narrators thus cause the audience to step out of, and back

27 Grimes, Ritual Criticism, 13.

28 Grimes, Ritual Criticism, 18-19.

29 Hüsken writes that the evaluation of rituals is "an intersubjective process, executed by groups or individuals. It is based on certain sets of values which might stem from canons which the participants themselves have not created, but it might equally be based on the expectations, intentions and agenda of individual participants...". Ute Hüsken, "Ritual Dynamics and Ritual Failure", in When Rituals Go Wrong. Mistakes, Failure and the Dynamics of Ritual, Numen Book Series 115, ed. Ute Hüsken (Leiden: Brill, 2007), 337-366, here 339. As a participant observer, I have been a frequent participant in the ritual of The Passion myself.

30 Grimes states that ritual criticism is contextualist, never absolute, always political, interested, negotiated, dialectical. It can be negative, but it is never just negative: it can also be constructive and at best reflexive. Grimes, Ritual Criticism, 14 .

31 The term 'infelicitous performance' was first used by John Austin in his speech act theory, and used by Ronald L. Grimes in the discussion of ritual evaluation. See Edward L. Schieffelin, "Introduction", in When Rituals Go Wrong, ed. Ute Hüsken, 1-2o. Also cf. Ronald L. Grimes, Ritual Criticism, 191-210. 
into the ritual frame. Their concluding interpretation, which also constitutes the introduction to the very final scene, thus functions as a break. In addition to this, from the 2016 edition onwards, the narrators' interpretations of the passion narrative have become more elaborate and the narrators have struck a different tone, both of which serve to increase the sense of stylistic break as the discourse takes on a somewhat didactic, even prophetic or kerygmatic character. This kind of stylistic shift may be something which is fitting in the context of a worship service, but it fails to work very well in the context of this public play. ${ }^{32}$ For a very brief moment, it turns the narrator into a preacher in disguise. From an emic perspective too, the interpretative speech can be seen as a performative infelicity, because it is at odds with the open and multi-interpretable character of the event. It also adds a ritual inconsistency: although it has been emphasised that the audience is free to choose what to believe and what not, the character and length of this speech suggests that the audience needs to be taught the meaning of the ritual in which they had just participated. Both from an outsider's and an insider's perspective, the words of the narrator at this point can be seen as a ritual 'mistake', not in the sense that they were 'mis-performed', but in the sense that the underlying ritual structure contains an error since the change of style results in a misfitting (sermon-like) element in this particular ludic ritual setting. ${ }^{33}$ The insertion of the sermonette constitutes, then, an internal inconsistency that could be understood as a failure to generate the proper tone or appropriate atmosphere (in Grimes' typology of infelicitous performances this is called a 'flop', as "all the procedures may be done correctly but the rite fails to resonate" ${ }^{\prime 34}$ ).

It is possible to push back on my ritual criticism of this moment on the basis of norms internal to the production: that the makers deliberately let the narrator zoom out in order to introduce the apparition of Jesus as a total surprise following on from the end of the play. The degree of surprise is, of course, relative, since after the first edition there has always been the promise of a spectacular final scene: the resurrection as a grand finale of light and sound. The makers have played with this surprise by offering the scene a new and different

32 Grimes points to the relevance of context when he writes: "What is a felicitous utterance in an ecclesiastical social context is infelicitous in the courts. Fenn demonstrates how context dependent the failure of ritual language is". Grimes, Ritual Criticism, 197 .

33 For more elaborate explorations of ritual mistakes and failures, cf. Hüsken, When Rituals Go Wrong.

34 Grimes, Ritual Criticism, 201. 
shape every year, but the promise of a grand finale has always been fulfilled. ${ }^{35}$ If this surprise has become a prevailing internal norm which influences the dramaturgic choice to have the narrator present an apparent conclusion, then the ultimate conclusion of the grand finale is a choice with theological implications; as was alluded to in a number of the later editions, it is implied that with God the end is not necessarily an end and that new beginnings always remain possible.

In the end, however, the question remains as to whether a didactic speech is required in order to prepare the audience for the surprise of Jesus' appearance. An explicit theological interpretation, however openly it may be formulated, seems unnecessary in light of the participant observation and analysis of the staged resurrection in this chapter, which has shown that the final scene of the event offers an embodied theology that is convincing in its own right. The sermonette thus tends to undermine the rest of the performance, depriving the ritual of its own expressive power as the apparition of Jesus becomes, to a certain extent, an illustration in the service of a didactic-cognitive speech, instead of a ritual with a sui generis character. Seen from a ritual perspective, The Passion, in its later editions, sells itself short at this point. The staged resurrection, and the practical theology that it embodies, need no verbal subtitling in any form whatsoever: they are strong enough to speak (and theologise) for themselves. As this chapter has shown, the creators of The Passion lucidly manage to perform theology around one of the most essential elements of Christianity within a late-modern 'secularised' culture. The importance of this theology's public character cannot be underestimated.

35 This is related to what producer Jacco Doornbos has called one of 'the rules of television' ('televisiewetten'): that people like to know what they are looking at. There must be "a clear promise to the TV viewer. And the promise of The Passion is very clear, because, as viewers, we all know the story and that is what we like, but we also like the surprise of who are playing the roles, and how it is shaped this time, and with which songs, and what touches us this time". Doornbos, interview, September 17, 2015 . 